Of particular scientific interest is the large programme of work now in progress on the quantitative aspects of fire in structures, both real and idealized. A particular object of this is to establish scaling laws for rate of burning, size of flames and the spread of fire by heat transmission from them, and the disposal of smoke by ventilation.

The statistical inquiries, as always, are interesting, and this year include reference to the incidence of fire in post-war houses, fires caused electrically, and aircraft crash incidents. Tests have been carried out on the relative effectiveness of audible warning devices in traffic, from which the traditional fire bell emerges rather badly. Preliminary experiments on the use of a gas turbine as an inert gas generator for extinguishing fires in large building spaces have given encouraging results. Fire-resistance testing of building materials, work on the prevention or mitigation of gas and dust explosions, and a number of other projects have been continued. J. H. BungoYNe

\title{
PROGRESS OF CANCER RESEARCH
}

\begin{abstract}
THE annual report of the British Empire Cancer Campaign continues to expand year by year; the thirty-eighth edition* is a massive book of nearly 800 pages, the scientists working either wholly or partly under the ægis of the Campaign number nearly 1,500 , and a million pounds was spent on research in 1960.
\end{abstract}

Some idea of the trends of cancer research, as described in the report, can be suggested by breaking down, into subject-matter and class, the total of papers published in 1960 by these investigators and comparing the resulting catalogue with that for 1950; the papers will, of course, represent the work more or less completed before 1960 rather than the present progress, but the main lines will undoubtedly remain substantially the same (Table 1). The table shows that in the ten years the trend has been to increase the volume of work on biochemical themes at the expense of carcinogenesis and radiobiology, and that the immunological and statistical approach is attracting more research.

Only a little of the large amount of research work detailed in the report can be referred to here. One of the most interesting investigations continues to be on the Gross leukæmia-inducing virus and the related polyoma virus. Miller confirms that removal of the thymus in $\mathrm{C} 3 \mathrm{H} f / G \mathrm{~S}$ mice at 3-4 months after they have been neo-natally inoculated with the Gross virus prevents the development of lymphocytic leukæmia which otherwise appears in 100 per cent of such inoculated mice. Grafting isogenic thymus into the thymectomized mice restores the growth potentiality of leukæmia. $\mathrm{C} 3 \mathrm{H}$ mice which had been made tolerant to tissue from $A k$ mice at birth were inoculated with normal $A k$ thymus and became leukæmic; transplantation tests showed that the lymphocytic neoplasm arose from host cells and not from the inoculated $A k$ cells, thus demonstrating that a non-cellular factor from $A k$ thymus is a necessary component in the origin of this lymphocytic leukæmia.

$C 3 H$ mice injected at birth with the Gross virus were later given a lethal dose of radiation and protected with normal isogenic marrow from untreated mice; most of the injected mice developed leukæmia, and tests with protecting cells carrying a marker chromosome indicated that the leukæmogenic virus is not only radio-resistant but is also resistant to any immune attack that might have been exerted by the protective marrow cells, and therefore there is not much hope of treating leukæmias of viral origin by total-body irradiation and marrow replacement.

* Britiah Empire Cancer Campaign. Thirty-eighth Annual Report covering the year 1960. Part 1: The Chairman's Statement and the
Accounts. Pp. xxxviii. Part 2: The Scientifle Report of the Aecounts. Pp. Xxxvil. Part undertaken by the Central Organlzation and its Autonomous Councils in the United Kingdom, and by some of its Affilated Organizations Overseas. Pp. xxxix-lvili + 792. (London: British Empire Cancer Campaign, 1961.)
Ambrose and colleagues, in experiments on normal and malignant cells grown in vitro, conclude that "The characteristic properties of the tumour cells so far suggested in the present studies are therefore as follows: (1) the tumour cell membranes show reduced mutual adhesiveness as compared with normal cells; (2) several lipases and phospholipases are more toxic for tumour cells than for normal cells and the tumour cells are also more sensitive to lipid in the medium, suggesting that more exposed lipid is present on the tumour cell membrane; (3) the structure of the tumour cell involves a less basic protein than the normal cell, suggesting a more acidic micro-climate at the cell surface, in agreement with the electrophoretic studies indicating an increased negative surface charge".

The possible cancer risks attached to the use of œstrogen implantation in cattle and poultry is the subject of a report by Sir Charles Dodds: "There has been a new interest in the alleged carcinogenic action of œstrogens during the past year. The widespread use of stilboestrol and hexoestrol in agrioulture has generally been approved by governments. Stilboestrol implantation in poultry for the purpose of caponisation has become almost universal and it is also estimated that a very large percentage of meat produced in the North American continent has been produced under the influence of stilboestrol, hexoestrol or some similar substance. There has been a change recently in the administrative outlook in the North American continent on the use of these substances and at the present time, in America, their use has been banned by what is known as the Delaney Amendment to an Act in the F.D.A. This whole question is being looked into and we have been particularly interested in attempts to assess the intake of ostrogens in a normal diet. This aspect of

Table 1. Papers pubuished on Cancer Regearch

$$
\text { Classification In } 1960 \begin{gathered}
\text { Total in } \\
1960 \\
\text { (per cent) }
\end{gathered} \text { In } 1950 \begin{gathered}
\text { Total in } \\
1950 \\
\text { (per cent) }
\end{gathered}
$$

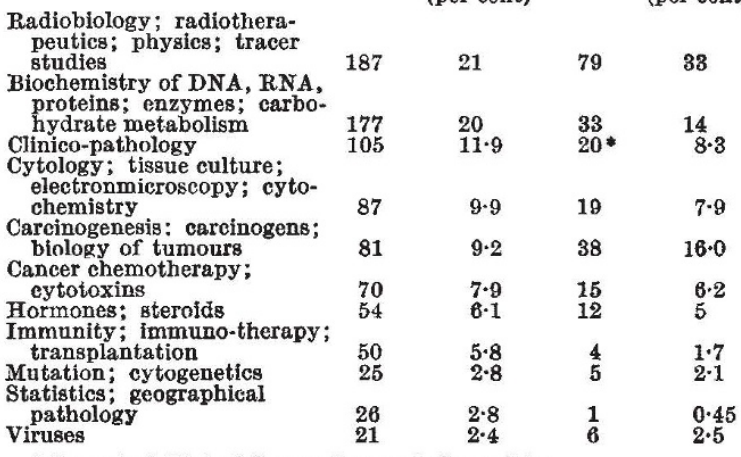

* Report of Clinical Cancer Research Committee. 
the problem seems to have been entirely overlooked by the legislators. There is, therefore, a renewed interest in compounds of the flavone and isoflavone series described later in this report".

Salaman and co-workers find that new-born mice are highly sensitive to carcinogens; after one year, of 26 mice of the '101' strain which had received $30 \mu$ of dimethylbenzanthracene neo-natally, 9 developed leukrmia, 25 lung adenoma, 7 skin papilloma and 16 papillomas of the forestomach.

Cunningham and colleagues at the Royal College of Surgeons have been studying eytologically the process of liver cancer induction by dimethylaminoazobenzene using a technique of section eutting which permits the life-like preservation of cellular structures in that mitochondria, free lipid, lipid-protein bonds and dehydrogenases are retained intact; the tissue being sectioned at $-25^{\circ}$ after cooling to $-70^{\circ}$.

Orr has been continuing his work on the chemical induction of mammary cancer in the mouse; such tumours did not develop in female mice of the $C 57 B 1$ strain after painting the skin with dimethylbenzan. thracene (DMBA) - a standard technique-but if the females were made pseudo-pregnant by being caged with vasectomized males and then painted with DMBA, 21 out of 29 mice developed breast tumours due to the added stimulus from progesterone in pseudo-pregnancy.

Orx and Mandi find that senile virgin rats are very liable to spontaneous mammary tumours; of 69 such females aged between 600 and 1,200 days, 34 (49 per cent) showed macroscopic fibroadenomata, while a parallel series of 46 female rats used for breeding had an incidence of only 4 per cent mammary tumours. "It is tentatively suggested in the light of these observations that continuous secretion of ostrogen by virgin animals, uninterrupted by phases of progesterone secretion during pregnancy, stimulates the anterior pituitary. The œstrogen-stimulated pituitary secretes appreciable quantities of luteotrophin even before it becomes enlarged, at the same time output of other gonadotrophins decreases. The secretion of luteotrophin would account for both the mammary hyperplasia and the presence of excessively large corpora lutea. Absence of corpora lutea could be explained by insufficiency of LH with failure of rupture of Graafian follicles".

Baldwin, at Nottingham, finds that a commercially available motor-engine oil additive is highly carcinogenic for mouse skin; it consists of a mixture of compounds which include lead naphthenate, carbon tetrachloride, 1,1,1,-trichloroethane and a petroleum oil base; the indications are that the active factor is present in the oil base.

King, Hughes and Louis at Melbourne, in interesting work on the fluorescein conjugate staining of tissues, state: "The studies of the last four years have been continued and extended. In addition to serum globulins, serum albumin has been conjugated with fluorescein and rhodamine. The differential avidity of the dyo for serum albumin as opposed to globulins has been confirmed. In addition, sera from species other than those previously examined have been invest. igated with similar results; normal tissues of all species studied stained but malignant tissues failed to stain.

"Tissues grown in tissue culture show the staining and fluorescence characteristic of normal tissues for the first three days. By the fourth day staining becomes patchy and subsequently no staining can be obtained, that is, after the fourth day the culture shows the same staining characteristics as malignant tissue. This conforms with observations made on re-introduction of such tissues into the original animal or one of the same species, when they grow in the same manner as true neoplasms".

In Melbourne also, Trautner and Coats have been using an ingenious technique in the study of species immunity to cancer; mouse ascites carcinoma cells were suspended in nutrient fluid in 'Perspex' chambers $(0 \cdot 1 \mathrm{ml}$.) fitted with non-reactive 'Millipore' filters of pore size $0 \cdot 6-0 \cdot 3 \mu$. "Attempts to transplant the tumour directly from the mouse to either the rat or the guinea pig were uniformly unsuccessful." When the chambers were inserted intraperitoneally in rats or guinea pigs the growth of the mouse cancer cells was at least as prolific as in mice. "It was found that growth of the tumour in the rats and guinea pigs was as good as or better than it had been in mice, and the day-by-day growth characteristics were studied. It would appear that the tumour-host hostility evident on direct inoculation was dependent on cell-to-cell contact between tumour cells and the host."

Studies in geographical pathology come from the University College of North Wales ("Cancer Incidence in Relation to Trace Elements in Soil and Plants"), Makerere College, Uganda ("Cancer in African Childron") and the University of Bristol.

Statistical data from the Bristol Tumour Registry show that under the age of 40 the English incidence of bone sarcoma is similar to Norwegian figures. After that age the tumour is much more common in south-west England, due largely but not entirely to the frequency of Paget's disease of bone in the English population, but not in the Norwegian population. Except in those subject to Paget's disease the tumour has a monomodal age incidence curve, the English incidence showing a typical bimodal curve.

Paget's disease (osteitis deformans), probably the commonest non-traumatic disease of bone seen in an orthopædic department, was deseribed in some detail in 1876 by Sir James Paget. It has been deseribed in animals, too, and is an etiological feature of canine osteogenic sarcoma, where it is much more common in some breeds than in others. The author of this study is clearly aware of the need to combine a knowledge of geographical pathology with genotics, comparative pathology and basic clinical observation in the elucidation of the most fundamental aspect of any disease -its natural history.

A report on a clinico-pathological investigation of cancer of the cervix uteri concludes that: (1) beyond a certain dosage (irradiation) range the physical modalities of irradiation do not significantly alter the cure-rate for cancer of the cervix; (2) the clinical extent of the disease and such quantitative biological characters as Broder's grade and size of tumour foci have a significant influence on the five-year survivalrate; (3) among the qualitative biological characters the histological type of the tumour and its ability to respond initially with an increase in differentiation profoundly affect the cure-rate; (4) systemic factors, of yet unknown character, ean control the growth of persisting cancers for long poriods.

The same, or similar, methods of treatment, unmodified in essentials for perhaps 20 years or more, are in use in hospitals throughout Britain, and naturally their reports read much the same. At present the clinician subscribes to earlier diagnosis as well as better surgery, irradiation or chemotherapy as one of the principal means of improving results. Not in all cases is this meaningful; the patient with an enlarged lymph node due to lymphosarcoma has 
both the earliest and the established pattern of the disease; the patient with a skin blemish can watch, if he wishes, the growth of a curable cutaneous eancer. Carcinoma of the lung is different from both; it produces symptoms (that is, something of which the patient complains) as a by-product of its naturally hidden position and will produce them when quite small should it simultaneously involve a blood vessel and a small peripheral bronchus, when blood-stained sputum may be expectorated, but commonly is measured in centimetres and produces the first symptoms due to remote spread. 'The size of a tumour, its duration or its elinical accessibility or visibility are not in themselves important in prognosis. The overriding factor is our knowledge based on experience of the natural history of each typo of tumour. For example, the prognosis in the case of squamous cell earcinoma depends on which organ it primarily involves, and extrapolation from one species to another must be done with extreme caution. Nevertheless, any basic studies of that neglected fieldanimal pathology-are most welcome. A complete understanding of tumour behaviour must include such knowledge, hence the work of Silver and Cater on the treatment of spontaneous tumours in animals by radiotherapy or by chemotherapoutic agents offers a little hope that research workers have not forgotten the value of comparative investigations.

Prof. Bullough's group at Birkbeck College continue work on the diurnal mitotic rhythm of normal mouse epidermis, and conclude that it is due to the hour-by-hour variations in the ability of prepared cells to enter division and not to hour-by-houx variations in the numbors of cells preparing to divide; that the ability of cells to enter division depends on variations in the secretion-rate of adrenalin; and that these variations in turn depend on a degree of stress felt by the animal, stress being higher when a mouse is awake than when it is asleep. On this fascinating work one could build, with little imagination, a hypothesis accounting for human cancer as, in part, a psychological disorder. (This has been attempted in the past with no convincirg success, but a careful psychosomatic approach to human cancer is worth while.)

With the chemotherapeutic agents at present available, one of the practical problems is that of delivering a dose of a drug which will result in the death of tumour cells, but which is not lethal to the patient; drugs with a greater specificity towards tumours are being developed while, at the same time, techniques using existing drugs aim at better localization. Where the tumour is in a limb, this becomes a fairly simple matter of perfusion; where the growth is widely disseminated, the urgent problem is to preserve a bone marrow which can regenerate after severe depression or even total death of bone marrow following administration of chemotherapeutic agents. Techniques vary from using living fotal marrow from a foetal tissue bank or the storage of the patient's own aspirated marrow for later re-injection, to an ingenious technique reported by Starr in New South Wales, where the patient's aspirated marrow is injected into a drill-hole in the tibia after a tourniquet is applied, only to be released after an otherwise lethal intravenous dose of cytotoxic drug has become fixed or eliminated, in $\mathbf{1}-3 \mathrm{hr}$.

At Makerere College, Uganda, animal tumours are investigated by exfoliative cytology, many tumour cells being studied to greater advantage when flattened on glass slides than in paraffin sections. In the case of the transmissible (venereal) tumour of the dog it has been found that the round cells infiltrating the lesions are plasma cells, frequently binucleate with a 'mirror image' pattern. In enzootic hæmaturia of cattle (a disease characterized by progression of papilloma of the bladder to carcinoma) investigations have confirmed the findings of some Turkish pathologists, and support a viral origin of the condition. These cytological observations show that the bovine urinary bladder has secretory function. Well-known virus diseases of animals-canine distemper and infectious pneumonitis of cats - are now being investigated by this rapid method of study.

As for many years past, the report provides plenty of evidence of the widespread use of physical techniques involving radiation and radioisotopes; this year there is evidence of the rapid extension of diagnostic and research uses of the latter in remote parts of the world. But there is little which is sufficiently novel to require mention. Hospital physicists, perennially suffering from erratic radiation background, will be interested to know that, at the Royal Cancer Hospital, an attempt is being made to build a low-background room on a small outlay of money. Chalk in paper bags, $2 \mathrm{ft}$. thick, is being used for this, the inner surface of the room being lined with $\frac{1}{4}$-in. aged lead. Another development which looks like being of practical importance is taking place at the Middlesex Hospital, where the radiation-induced destruction of the fluorescence of quinine sulphate is being investigated as a method of measuring $\gamma$ - and $\mathrm{X}$-ray dosage. The results suggest that doses of 10 rads or even less can be estimated with good accuracy; it will be interesting to hear further of this work.

Among radiotherapeutic developments note should be taken of the Royal Cancer Hospital's use of solid sources which have been made radioactive by neutron bombardment. These include a Souttar's tube, for treatment of the osophagus, made of silver-plated nickel wire containing a core of gold; and two laryngectomy tube applicators of copper-nickel alloy, giving, after activation, a dose-rate of the order of 200 rads $/ \mathrm{hr}$. The Department of Radiotherapeutics at Cambridge has continued its efforts, noted here last year, to use the selective uptake of tritiated 'Synkavit' in cancer as a therapeutic measure. Information is given on methods of administration, dosage, and means for increasing selective concentration. Information is also given on the degree of selective uptake in various types of tumour-tissue as compared with bone-marrow. Investigations, subject to the usual limitations, have been made on patients and the results are so far inconclusive. On the other hand, parallel investigations on animals which are also reported look promising. A similar line of investigation is reported from the Sheffield Regional Radiotherapy Centre, where the selective uptake of radioactive zinc-labelled hæmatoporphyrin has been investigated with encouraging results; however, no details are given.

The Leeds centre is making a new approach to the study of bone mineralization. Attempts are being made to relate the transmission through bone of radiations of markedly different quality to the quantity of calcified bone lying in the path of the beam. Thulium-170 and cæsium-137 have been used in this work which, if successful, will make it possible to study bone mineralization by in vivo methods.

D. G. ARNo'Tt

I. Hifger

A. L. IAEVENE 